\title{
Pengembangan Perangkat Pembelajaran IPA Berorientasi pada Taxonomy for Science Education di Sekolah Dasar
}

\author{
Imanuel Sairo Awang' \& Andri²
}

1,2STKIP Persada Khatulistiwa Sintang

1,2Jl. Pertamina-Sengkuang, Sintang

'Email: imanuel.s.a@stkippersada.ac.id

2Email: andri@stkippersada.ac.id

\begin{tabular}{|c|c|}
\hline ABSTRACT & ABSTRAK \\
\hline $\begin{array}{l}\text { The learning method has been focused on } \\
\text { student cognitive. In the mean time, student } \\
\text { should accept comprehensively. This research is } \\
\text { aim to develop learning kits of natural science } \\
\text { that taxonomy for science education oriented in } \\
\text { elementary school. The kits consist of domain I } \\
\text { (imagine and understanding), domain II (science } \\
\text { process skills), domain III (imagine and creativity), } \\
\text { domain IV (attitude and value), and domain V } \\
\text { (conection and applying). This is a research and } \\
\text { development method, with subjects were both } \\
\text { of fourth grade elementary school students of SD } \\
\text { negeri } 20 \text { Mambok and SD Negeri } 5 \text { Sintang. The } \\
\text { results of evaluation of learning science experts } \\
\text { to examine the validity of the learning kits stated } \\
\text { valid. Then, the trial results showed that the } \\
\text { learning kits was developed to meet the criteria } \\
\text { of effective to use in elementary school. It } \\
\text { concludes that the learning kits of natural } \\
\text { science that taxonomy for science education } \\
\text { oriented is able to applied in elementary school. } \\
\text { v }\end{array}$ & $\begin{array}{l}\text { Selama ini pembelajaran hanya berfokus pada } \\
\text { kognitif siswa. Sementara siswa harus menerima } \\
\text { materi secara komprehensif. Penelitian ini } \\
\text { bertujuan untuk mengembangkan perangkat } \\
\text { pembelajaran IPA yang berorientasi pada } \\
\text { taxonomy for science education. Di mana } \\
\text { taxonomy for science education meliputi lima } \\
\text { ranah hasil belajar yaitu Ranah I (Knowing and } \\
\text { Understanding); Ranah II (Science Process Skills); } \\
\text { Ranah III (Imagine and Creativity); Ranah IV } \\
\text { (Attitude and Value); dan Ranah V (Conection } \\
\text { and Applying). Penelitian ini dilaksanakan } \\
\text { dengan metode research and development, } \\
\text { dengan siswa kelas IV SD Negeri } 20 \text { Mambok dan } \\
\text { siswa kelas IV SD Negeri } 5 \text { Sintang sebagai subjek } \\
\text { ujicoba. Hasil evaluasi oleh ahli menunjukkan } \\
\text { bahwa perangkat pebelajaran berorientasi } \\
\text { pada taxonomy for science education valid } \\
\text { untuk digunakan. Sedangkan hasil ujicoba } \\
\text { menunjukkan bahwa perangkat pebelajaran } \\
\text { berorientasi pada taxonomy for science } \\
\text { education efektif digunakan di sekolah dasar. } \\
\text { Simpulan dari penelitian ini adalah perangkat } \\
\text { pembelajaran ipa berorientasi pada taxonomy } \\
\text { for science education layak digunakan di } \\
\text { sekolah dasar. } \\
\text { Kata Kunci: perangkat pembelajaran; taxonomy } \\
\text { for science education; sekolah dasar }\end{array}$ \\
\hline
\end{tabular}

How to Cite: Awang, I., \& Andri, A. (2017). Pengembangan Perangkat Pembelajaran IPA Berorientasi pada Taxonomy for Science Education di Sekolah Dasar. Mimbar Sekolah Dasar, 4(3), $192-202$. http://doi.org/10.17509/mimbar-sd.v4i3.8411.

\begin{abstract}
PENDAHULUAN Pendidikan adalah unsur penting bagi pengembangan potensi manusia agar siap menghadapi segala permasalahan dalam kehidupannya. Pendidikan mendapat perhatian utama berkaitan dengan pengembangan
\end{abstract}

peradapan suatu bangsa. Oleh karena itu, usaha untuk menjadikan pendidikan sebagai penyangga utama perkembangan suatu bangsa perlu terus ditingkatkan. 
Imanuel Sairo Awang \& Andri, Pengembangan Perangkat Pembelajaran IPA...

Peningkatan kualitas pendidikan dapat dilakukan melalui berbagai komponen dalam pembelajaran. Berbagai komponen dalam pembelajaran yang dapat tingkatkan kualitasnya adalah penggunaan media pembelajaran dan sumber belajar yang bervariasi. Selain itu, peningkatan kualitas pembelajaran juga dapat dilakukan dengan cara mengatur suasana pembelajaran yang meliputi pemilihan strategi, pendekatan, metode, teknik, serta taktik yang sesuai agar pembelajaran menjadi lebih efektif dan menyenangkan.

Pembelajaran yang efektif dan menyenangkan terutama pada jenjang sekolah dasar sangat diperlukan. Hal ini dikarenakan sesuai dengan tingkat perkembangan mental serta emosional siswa. Siswa usia sekolah dasar berada pada tahap perkembangan operasi konkret. Implikasinya adalah guru harus mampu memberikan pengalaman belajar yang nyata agar dapat diterima dengan baik oleh siswa.

Pembelajaran yang hanya memfokuskan pada ranah kognitif hanya akan menjauhkan pengetahuan dengan siswa. Siswa dipaksa untuk memahami pengetahuan yang diberikan oleh guru sebagai pemenuhan dari standar kompetensi yang ditetapkan. Sebagai akibatnya pengetahuan yang diterima oleh siswa bersifat sementara. Oleh karena itu, pembelajaran yang mengedepankan hasil yang seimbang dan holistik mutlak diperlukan, dimana tidak hanya ranah kognitif yang dikembangkan, namun juga ranah afektif, dan psikomotorik.

Dalam pelaksanaannya, pembelajaran berbasis ranah Bloom masih belum seimbang dan holistik yaitu umumnya hanya menitikberatkan pada tujuan ranah kognitif dan menghindari tujuan ranah afektif (Collete-Chiapetta, dalam Prasetyo, 2008, p. 21). Sebagai akibatnya, pembelajaran menjadi monoton dan tidak memberi peluang siswa berperan aktif. Perluasan dari pembelajaran berbasis ranah Bloom diperlukan untuk mengeksplorasi potensi siswa dimana tidak hanya kemampuan kognitif tetapi juga ranah yang lain, terutama pada mata pelajaran IPA.

IImu Pengetahuan Alam (IPA) atau science (bahasa Indonesia: sains) diambil dari kata Latin Scientia yang memiliki arti harfiah pengetahuan. Menurut Oxford English Dictionary (Buxton \& Provenzo, 2007, p. 6) sains didefinisikan sebagai, "Those branches of study that related to the phenomena of the material universe and their laws". Pendapat tersebut menjelaskan bahwa IPA merupakan cabang ilmu yang berhubungan dengan fenomena-fenomena yang terdapat di alam serta hukum-hukum yang berlaku padanya. Dengan demikian, pembelajaran IPA di sampaikan di sekolah agar siswa memahami secara baik bagaimana alam semesta berlaku. 
Menurut Sumaji, dkk. (Awang, 2012), "Pembelajaran IPA di SD hendaknya membuka kesempatan untuk memupuk rasa ingin tahu peserta didik secara ilmiah. Dengan demikian, pembelajaran IPA yang disampaikan harus dirancang sedemikian rupa sehingga semua potensi yang terdapat dalam diri siswa dapat terakomodasi. Salah satu pembelajaran yang dapat mengakomodasi seluruh potensi siswa adalah pembelajaran yang berorientasi pada taxonomy for science education.

Taxonomy for science education adalah sebuah acuan pembelajaran dalam pendidikan sains, yang mampu meningkatkan aktivitas pembelajaran IPA di kelas dan mengembangkan sikap positif terhadap mata pelajaran itu (LoucksHorsley, et al., 1990). Taxonomy for science education diyakini merupakan perluasan dari ketiga ranah hasil belajar Bloom. Taxonomy for science education meliputi lima ranah hasil belajar yakni Ranah I (Knowing and Understanding); Ranah II (Science Process Skills); Ranah III (Imagine and Creativity); Ranah IV (Attitude and Value); dan Ranah $\vee$ (Conection and Applying) (MacCormack \& Yager, dalam Prasetyo, 2008, p. 18). Sesuai dengan uraian tersebut, maka salah satu acuan pembelajaran yang patut dikembangkan adalah pembelajaran yang berorientasi pada taxonomy for science education.

Taxonomy for science education adalah sebuah acuan pembelajaran dalam pendidikan sains, yang mampu meningkatkan aktivitas pembelajaran IPA di kelas serta dapat meningkatkan minat siswa terhadap mata pelajaran IPA. Taxonomy for science education (Prasetyo, 1998) meliputi lima ranah hasil belajar yakni Ranah I (Knowing and Understanding); Ranah ॥ (Science Process Skills); Ranah III (Imagine and Creativity); Ranah IV (Attitude and Valve); dan Ranah $\vee$ (Conection and Applying).

Ranah I merupakan acuan hasil belajar yang berfokus pada pengetahuan. Pendidikan IPA mempunyai fakta, konsep, prinsip, hukum, dan teori yang harus dikuasai oleh siswa. Melalui penekanan pada ranah ini, siswa diharapkan dapat mengetahui serta memahami pengetahuan IPA. Selanjutnya, ranah II merupakan acuan hasil belajar yang berfokus pada keterampilan proses IPA. Pengetahuan yang berkaitan dengan fakta, konsep, prinsip, hukum, dan teori dalam pendidikan IPA diperoleh melalui suatu proses yakni dengan metode ilmiah. Penerapan metode ilmiah dalam memperoleh pengetahuan dilaksanakan dengan melakukan berbagai kegiatan diantaranya pengamatan, pengukuran, pengelompokkan, pengkomunikasian, sampai pada keterampilan melakukan eksperimen. Melalui penekanan pada ranah ini, siswa diharapkan dapat menguasai keterampilan proses IPA tingkat dasar. 
Imanuel Sairo Awang \& Andri, Pengembangan Perangkat Pembelajaran IPA...

Ranah III merupakan acuan hasil belajar yang berfokus pada kemampuan menginterpretasi produk pengetahuan khususnya pengetahuan IPA. Keterampilan ini harus dikuasai agar dapat memahami secara utuh pengetahuan IPA. Sementara ranah IV merupakan acuan hasil belajar yang berfokus pada pengembangan nilai dan sikap dalam belajar IPA. Pengetahuan diperoleh dengan sikap jujur dan teliti. Setelah mengetahui produk IPA, siswa juga diharapkan dapat mengaktualisasi nilainilai yang terkandung di dalamnya. Keterampilan ini harus dikuasai agar siswa mampu bersikap positif serta menerapkan nilai-nilai kehidupan dengan baik pula. Kemudian ranah $\vee$ dari taxonomy for science education adalah acuan hasil belajar yang berfokus pada penerapan dari pengetahuan yang telah diperoleh. Muara dari produk IPA adalah teknologi. Sehingga diharapkan dengan diacunya ranah ini dalam pembelajaran IPA siswa terbiasa untuk menghasilkan sebuah karya sebagai bentuk pemahaman dari pengetahuan IPA.

Perangkat pembelajaran berorientasi taxonomy for science education yang dikembangkan dalam penelitian ini meliputi silabus, rencana pelaksanaan pembelajaran (RPP), lembar kerja siswa (LKS) dan lembar penilaian. Silabus merupakan rencana pembelajaran pada suatu/pokok mata pelajaran tertentu yang mencakup standar kompetensi, kompetensi dasar, materi pokok/pembelajaran, kegiatan pembelajaran, indikator pencapaian kompetensi untuk penilaian, alokasi waktu dan sumber belajar (Depdiknas, 2007b, p. 4). Tahapan pengembangan silabus adalah: (1) mengkaji dan menentukan standar kompetensi; (2) mengkaji dan menentukan kompetensi dasar; (3) mengidentifikasi materi pokok pembelajaran; (4) mengembangkan kegiatan pembelajaran; (5) merumuskan indikator pencapaian kompetensi; (6) menentukan jenis penilaian; serta (7) menentukan alokasi waktu, dan (8) menentukan sumber belajar.

Rencana pelaksanaan pembelajaran (RPP) dijabarkan dari silabus untuk mengarahkan kegiatan belajar peserta didik dalam upaya mencapai kompetensi dasar (Depdiknas, 2007b, p. 4). Komponen substansial RPP meliputi: standar kompetensi, kompetensi dasar, indikator, alokasi waktu, model/strategi/metode pengajaran, kegiatan pembelajaran (disusun tiap pertemuan), alat/bahan, penilaian, dan sumber belajar. RPP disusun untuk setiap kompetensi dasar. Bagian penting lainnya dalam penyusunan RPP adalah indikator. Indikator merupakan penanda pencapaian kompetensi dasar yang ditandai oleh perubahan perilaku yang dapat diukur sesuai dengan lima domain Ranah I (knowing and understanding); Ranah II (science process skills); Ranah III (imagine and creativity); Ranah IV (attitude and value); dan Ranah $\checkmark$ (conection and applying). 
Selanjutnya penyusunan lembar kerja siswa (LKS) biasanya berupa petunjuk, langkah-langkah untuk menyelesaikan suatu tugas sesuai dengan kompetensi dasar. LKS adalah materi ajar yang dikemas secara integrasi sehingga memungkinkan peserta didik mempelajari materi tersebut secara mandiri. LKS digunakan untuk mengoptimalkan hasil belajar peserta didik dan meningkatkan kegiatan belajar peserta didik di sekolah maupun di rumah.

Bagian terakhir dari perangkat pembelajaran adalah lembar penilaian. Penilaian adalah proses pengumpulan dan pengolahan informasi untuk menentukan pencapaian hasil belajar peserta didik (Depdiknas, 2007a, p. 3). Tujuan dan fungsi penilaian salah satunya adalah sebagai pengukur keberhasilan. Pada penilaian ini dimaksudkan untuk mengetahui sejauh mana suatu program berhasil diterapkan.

Mengingat pendidikan IPA mempunyai kekhususan tersendiri, maka munculnya taxonomy for science education diharapkan dapat mengakomodasi keunikan dari pembelajaran pendidikan IPA. Selain itu, kelima ranah pada taxonomy for science education diharapkan dapat meningkatkan aktivitas dan minat, serta kemampuan kognitif siswa. Terkait dengan masalah di atas, maka untuk mengkaji lebih dalam tentang kelayakan dan keefektifan perangkat pembelajaran setelah melaksakan pembelajaran yang berorientasi pada taxonomy for science education peneliti ingin melakukan penelitian dengan tujuan untuk mengembangkan perangkat pembelajaran IPA berorientasi pada taxonomy for science education di sekolah dasar.

\section{METODE}

Penelitian ini dilakukan dengan model penelitian dan pengembangan (research and development). Sukmadinata (2006, p. 164) menyatakan bahwa penelitian dan pengembangan adalah suatu proses atau langkah-langkah untuk mengembangkan produk baru atau menyempurnakan produk yang telah ada, yang dapat dipertanggungjawabkan. Langkahlangkah dalam proses penelitian dan pengembangan menunjukkan suatu siklus, yang diawali dengan adanya suatu kebutuhan, sampai permasalahan yang membutuhkan pemecahan dengan menggunakan suatu produk tertentu.

Langkah-langkah dalam penelitian ini mengikuti langkah dari Borg, Gall, \& Gall (2003) yang terdiri dari sembilan langkah dan dimodifikasi dengan model 4-D dari Thiagarajan (Thiagarajan, Semmel, \& Semmel, 1974) yakni: (1) studi pendahuluan, (2) perencanaan, (3) mengembangkan produk awal, (4) uji coba awal, (5) revisi produk utama, (6) melakukan uji coba lapangan, (7) revisi terhadap produk operasional, (8) uji coba lapangan produk operasional, dan (9) revisi produk final. 
Imanuel Sairo Awang \& Andri, Pengembangan Perangkat Pembelajaran IPA...

Subjek uji coba dalam penelitian ini adalah siswa kelas IV SD Negeri 20 Mambok, Sintang. Sedangkan subjek penelitian uji coba lapangan adalah siswa kelas IV SD Negeri 5 Sintang. Adapun intrumen yang digunakan yakni lembar validasi, tes hasil belajar, lembar pengamatan, dan portofolio. Lembar validasi digunakan untuk menilai kelayakan perangkat pembelajaran yang dikembangkan. Sedangkan lembar tes, lembar pengamatan, dan portofolio siswa digunakan untuk menilai tingkat keefektifan penerapan perangkat pembelajaran yang dikembangkan.

Analisis data untuk mengetahui kevalidan dilakukan dengan melakukan analisis kelayakan oleh ahli pembelajaran IPA tentang taxonomy for science education. Proses ini dilaksanakan dengan meminta ahli mengisi lembar penilaian yang telah disiapkan. Setelah itu dilakukan analisis keefektifan yang dilakukan menggunakan statistik deskriptif terhadap tes hasil belajar, lembar pengamatan, dan portofolio. Kriteria yang ditentukan adalah, apabila terdapat paling sedikit $80 \%$ ketuntasan maka, dinyatakan efektif.

\section{HASIL}

Pada tahap awal, dilakukan perancangan perangkat pembelajaran yang terdiri dari silabus, rencana pelaksanaan pembelajaran (RPP), lembar kerja siswa (LKS) dan lembar penilaian. Semua unsur perangkat pembelajaran ini dirancang dengan berorientasi pada taxonomy for science education. Setelah dirancang, langkah selanjutnya adalah melakukan tahapan validasi yang dilakukan oleh ahli pembelajaran IPA berorientasi taxonomy for science education. Penilaian dilakukan dengan cara mengisi lembar penilaian pada masing-masing komponen. Hasil rekapitulasi penilaian dari ahli pembelajaran IPA secara lengkap dapat dilihat pada Tabel 1.

Tabel 1. Data Hasil Penilaian Kevalidan Perangkat Pembelajaran oleh Ahli Pembelajaran IPA

\begin{tabular}{clcc}
\hline \multirow{2}{*}{ No. } & Komponen Perangkat Pembelajaran & Total Skor Aktual & Kategori \\
\hline 1. & Silabus & $(\mathbf{X})$ & Baik \\
2. & RPP & 41 & Baik \\
3. & LKS dan Kunci LKS & 71 & Baik \\
4. & Lembar Penilaian dan Kunci & 36 & Baik \\
\hline
\end{tabular}

Berdasarkan penilaian dari ahli pembelajaran IPA, beberapa aspek perlu direvisi. Aspek tersebut meliputi konstruk pada LKS dan lembar penilaian. Selain itu, pada teknik pelaksanaan pembelajaran, perlu ditekankan pada proses pembimbingan yang intensif agar siswa memahami perintah di LKS dengan baik. Setelah direvisi selanjutnya dilakukan ujicoba terbatas di Sekolah Dasar Negeri No. 20 Mambok. Ujicoba dilakukan untuk melihat keefektifan pelaksanaan 
pembelajaran berorientasi taxonomy for science education. Hasil penilaian keefektifan perangkat pembelajaran berorientasi taxonomy for science education pada ujicoba terbatas dapat dilihat pada Tabel 2.

Tabel 2. Rekapitulasi Hasil Penilaian Keefektifan Perangkat Pembelajaran pada Ujicoba Terbatas

\begin{tabular}{clccc}
\hline No. & Komponen Keefektifan & Rerata Total Skor Aktual & Ketuntasan (\%) & Kategori \\
\hline 1. & Hasil Tes Siswa & 87,64 & 100 & Sangat Baik \\
2. & Lembar Pengamatan & 63,18 & 92,92 & Sangat Baik \\
3. & Penilaian Portofolio & 78,8 & 48,15 & Kurang \\
\hline
\end{tabular}

Hasil penilaian pada Tabel 2, menunjukkan bahwa pada komponen tes siswa, rerata hasil tes siswa sudah melampaui kriteria yang ditentukan yakni kriteria ketuntasan minimal sebesar 80. Walaupun rata-rata siswa sudah mencapai kriteria yang ditentukan, namun masih terdapat beberapa siswa saat dilaksanakan pengamatan pada saat kegiatan pembelajaran, masih belum optimal dalam melaksanakan tugas yang diberikan guru. Hasil pengamatan terhadap aktivitas siswa secara berkelompok memperlihatkan persentase sebesar 92,92\%. Artinya secara umum siswa mampu menunjukkan sikap dan prilaku yang mendukung pelaksanaan pembelajaran taxonomy for science education.

Mengingat masih terdapat berbagai kendala dalam pelaksanaan pembelajarannya, maka dilakukan revisi pada beberapa bagian terhadap perangkat pembelajarannya. Selain itu, pada saat penerapannya di kelas juga harus diperhatikan teknik penyampaian agar siswa tidak menemui kendala yang berarti. Revisi yang dilakukan yakni, pada rencana pelaksanaan pembelajaran (RPP), pemilihan contoh benda yang mempunyai tiga wujud dilakukan dengan lebih banyak.

Pada materi tentang "benda dapat melarutkan benda lain", guru diminta untuk dapat memberikan lebih banyak contoh dan bimbingan yang intensif kepada siswa. Dengan demikian diharapkan mereka mampu menyelesaikan tugas di LKS dengan baik. Secara teknik penerapannya juga dilakukan penjelasan dengan lambat. Sehingga siswa dapat mengikuti dan memahami dengan baik. Pada lembar kerja siswa (LKS), hanya direvisi pada tahap penerapannya. Siswa harus dibimbing secara pelan-pelan agar mereka dapat mengikuti arahan dengan baik.

Setelah dilakukan revisi, maka dilanjutkan dengan melaksanakan ujicoba terakhir yakni ujicoba lapangan. Ujicoba lapangan untuk mengetahui keefektifan perangkat pembelajaran berorientasi 
Imanuel Sairo Awang \& Andri, Pengembangan Perangkat Pembelajaran IPA...

taxonomy for science education ini dilaksanakan di Sekolah Dasar Negeri 5 sintang. Hasil ujicoba lapangan perangkat pembelajaran berorientasi taxonomy for science education dapat dilihat pada Tabel 3.

Tabel 3. Rekapitulasi Hasil Penilaian Keefektifan Perangkat Pembelajaran pada Ujicoba Lapangan

\begin{tabular}{clccc}
\hline No. & Komponen Keefektifan & Rerata Skor Aktual & Ketuntasan (\%) & Kategori \\
\hline 1. & Hasil Tes Siswa & 88,34 & 100 & Sangat baik \\
2. & Lembar Pengamatan & 61,75 & 90,81 & Sangat baik \\
3. & Penilaian Portofolio & 81,70 & 81,25 & Sangat baik \\
\hline
\end{tabular}

Perangkat pembelajaran merupakan hal penting dan mendasar yang harus disiapkan oleh seorang guru ketika akan melaksanakan kegiatan pembelajaran. Perangkat pembelajaran yang baik adalah perangkat pembelajaran yang disusun berdasarkan kondisi serta potensi yang dimiliki oleh lingkungan pembelajaran. Selain itu, perangkat pembelajaran yang baik juga dapat dilihat dari kesesuaian antara perangkat yang satu dengan perangkat dukungan yang lain. Dalam penelitian ini telah dirancang perangkat pembelajaran yakni silabus, rencana pelaksanaan pembelajaran (RPP), lembar kerja siswa (LKS), dan lembar penilaian, di mana semua perangkat tersebut berorientasi pada taxonomy for science education.

\section{PEMBAHASAN}

Taxonomy for science education pertama kali dikembangkan oleh MacCormack \& Yager (Prasetyo, 2008, p. 18), yang merupakan pengembangan hasil belajar dari taksonomi Bloom. Taxonomy for science education merupakan sebuah konsep pengelompokkan hasil belajar terutama pada mata pelajaran IImu Pengetahuan Alam (IPA) menjadi lima bagian (ranah). Kelima ranah tersebut yakni ranah I (knowing and understanding); ranah II (science process skills); ranah III (imagine and creativity); ranah IV (attitude and value); dan ranah $\mathrm{V}$ (conection and applying).

Taksonomi pembelajaran sains ini diyakini merupakan pengembangan dari tiga ranah taksonomi pembelajaran Bloom. Kelima ranah hasil belajar sains ini mencoba untuk mengembangkan berbagai keterampilan yang harus dikuasai oleh seseorang yang belajar sains. Sehingga, apabila seseorang atau siswa yang belajar sains, tidak hanya befokus pada pencapaian tujuan kognitifnya, melainkan juga menguasai hal-hal yang berkaitan dengan pengusaan kognitif tersebut.

Penelitian ini bertujuan untuk mengetahui karateristik pembelajaran berorientasi pada taxonomy for science education. Selain itu, penelitian ini juga ingin mengetahui tingkat kelayakan dan 
keefektifan pembelajaran dengan menggunakan perangkat pembelajaran berorientasi pada taxonomy for science education. Pada langkah awal, dirancang perangkat pembelajaran berorientasi pada taksonomi for science education dengan mengintegrasikan silabus, RPP, LKS, dan lembar penilaian.

Berdasarkan hasil validasi dari ahli pembelajaran IPA dapat diketahui bahwa rata-rata skor setiap komponen perangkat pembelajaran berada pada kategori "baik" dengan rincian hasil penilaian silabus berkategori "baik"; hasil penilaian RPP berkategori "baik"; hasil penilaian LKS berkategori "baik"; dan hasil penilaian lembar penilaian berkategori "baik". Hal ini mengindikasikan bahwa meskipun terdapat berbagai revisi berdasarkan saran dan masukan dari validator, produk awal perangkat pembelajaran berorientasi pada taxonomy for science education tersebut sudah layak digunakan pada ujicoba.

Keefektifan perangkat pembelajaran IPA berorientasi pada dilihat dari hasil tes, hasil pengamatan, dan hasil portofolio siswa. Hasil tes diberikan setelah melaksanakan kegiatan pembelajaran, kemudian hasil pengamatan dilaksanakan selama penerapan RPP yakni sebanyak empat kali pertemuan. Sedangkan hasil portofolio siswa diberikan pada akhir pelaksanaan pembelajaran pertemuan keempat.
Pada pembelajaran yang berorientasi pada taxonomy for science education, selain mengembangkan kemampuan berpikir (aplikasi ranah I), siswa juga diajak untuk mengeksplorasi materi melalui kegiatan dengan melibatkan keterampilan proses sains (aplikasi ranah II). Keterampilan proses sains merupakan keterampilan yang harus dimiliki agar mereka dapat melaksanakan aktivitas keilmuan melalui metode ilmiah. Melalui kegiatan pengamatan, pengelompokkan, diskusi (berkomunikasi), menyimpulkan, dan presentasi, siswa mampu membangun konsep pemahaman sesuai dengan pengalaman belajar yang ia miliki.

Hasil pengamatan juga menunjukkan bahwa ranah IV taxonomy for Science Education yakni attitude and value berkembang dengan baik. Ini dapat dilihat dari pelaksanaan pembelajaran baik secara pribadi maupun berkelompok mereka menunjukkan sikap rasa ingin tahu, sikap berpikir kritis, dan sikap berpikiran terbuka dan kerjasama. Perilaku yang menunjukkan sikap rasa ingin tahu, sikap berpikir kritis, dan sikap berpikiran terbuka dan kerjasama tersebut terlihat dari sikap antosias siswa saat kegiatan pembelajaran berlangsung, selain itu, semua siswa menerima pembagian kelompok dan menerima tugas dengan sikap positif dengan rasa ingin tahu nyang tinggi. Hal ini karena masing-masing anggota kelompok bertanggung jawab untuk menyelesaikan tugas yang diberikan 
Imanuel Sairo Awang \& Andri, Pengembangan Perangkat Pembelajaran IPA...

dalam LKS. Dalam penelitian ini, sebagaimana yang dilaporkan Khotimah \& Suliyanah (2017), optimalisasi LKS akan turut memberikan pengaruh yang besar dalam meningkatkan kemampuan belajar IPA siswa.

Pada hasil penilaian portofolio siswa menunjukkan bahwa, ranah III dan ranah $\checkmark$ yakni (imagine and creativity) dan (conection and applying) berkembang dengan baik. Siswa mampu mengembangkan daya khayalnya (imagine) dalam membuat tiruan model yang diminta. Dari khayalannya, tercipta sebuah kreativitas (creativity). Kemudian, dari kreativitas tersebut, mereka mampu menghubungkan materi yang diperlajari (conection) serta dapat menerapkan konsep-konsep yang telah dipelajarinya (applying).

Secara umum berdasarkan hasil analisis dan pembahasan yang telah diuraikan, maka dapat diambil kesimpulan bahwa perangkat pembelajaran IPA berorientasi pada taxonomy for science education yang telah dikembangkan efektif digunakan pada proses pembelajaran IPA di sekolah dasar, terlebih karena perangkat pembelajaran yang dikembangkan lebih berorientasi pada pemecahan masalah (Sulistiono \& Rahayu, 2014).

\section{SIMPULAN}

Berdasarkan hasil analisis data dan pembahasan, maka kesimpulan dari penelitian ini adalah: (1) perangkat pembelajaran IPA berorientasi pada taxonomy for science education mempunyai karakteristik yakni perangkat pembelajaran IPA yang dikembangkan terdiri dari silabus, rencana pelaksanaan pembelajaran (RPP), lembar kerja siswa (LKS), dan lembar penilaian; (2) Perangkat pembelajaran IPA berorientasi pada Taxonomy For Science Education dengan lima ranah hasil belajar yaitu Ranah I (knowing and understanding); Ranah II (science process skills); Ranah III (imagine and creativity); Ranah IV (attitude and value); dan Ranah $\vee$ (conection and applying); dan (3) Perangkat pembelajaran IPA berorientasi pada taxonomy for science education efektif diterapkan pada pembelajaran IPA di sekolah dasar.

\section{REFERENSI}

Awang, I.S. (2012). Pengembangan Subject Specific Pedagogy (SSP) Mata Pelajaran IPA Untuk Mengembangkan Karakter Peserta Didik Sekolah Dasar. Jurnal Pendidikan Vox Edukasi. 3 (1). 110.

Borg, W.R., Gall, M.D., \& Gall. J.P. (2003). Educational research: an introduction. ( $7^{\text {th }}$ Ed). New York. Pearson Education. Inc.

Buxton, C.A. \& Provenzo, E.F. (2007). Teaching science in elementary and middle school: a cognitive and cultural approach. Los Angeles. Sage Publications, Inc.

Depdiknas. (2007a). Peraturan Menteri Pendidikan Nasional Republik Indonesia Nomor 20, Tahun 2007, tentang Standar Penilaian Pendidikan. 
Depdiknas. (2007b). Peraturan Menteri Pendidikan Nasional Republik Indonesia Nomor 41, Tahun 2007, tentang Standar Proses untuk Satuan Pendidikan Dasar dan Menengah.

Khotimah, P.C. \& Suliyanah. (2017). Pengembangan lembar kerja siswa (LKS) untuk melatihkan keterampilan berpikir kritis peserta didik SMAN 4 Sidoarjo pada materi kalor. Inovasi Pendidikan Fisika (JIPF), 6(03), 295-300.

Loucks-Horsley, S., et al. (1990). Elementary school science for the '90's. Andover, MA. Network.

Prasetyo, Z. K. (2008). Kontribusi pendidikan sains dalam pengembangan moral peserta didik. Pidato Pengukuhan Guru Besar dalam Bidang Ilmu Pendidikan IPA pada Fakultas Matematika dan IImu Pengetahuan Alam Universitas Negeri Yogyakarta. 5 Januari 2008, Yogyakarta, Indonesia.

Prasetyo, Z.K. (1998). Taksonomi untuk pendidikan fisika (sains) Yogyakarta: Cakrawala Pendidikan Majalah IImiah Kependidikan. Edisi Khusus Dies. 146151.

Sukmadinata, N. S. (2006). Metodologi penelitian pendidikan. Bandung. PT Remaja Rosdakarya.

Sulistiono, E., \& Rahayu, Y. S. (2014). PENINGKATAN KEMAMPUAN BERPIKIR KRITIS SISWA MENGGUNAKAN PERANGKAT PEMBELAJARAN IPA SMP BERORIENTASI PENYELESAIAN MASALAH. Jurnal Pena Sains, 1 (2), 46-55.

Thiagarajan, S., Semmel, D.S., \& Semmel, M.I. (1974). Instructional development for training teachers of exceptional children A Sourcebook. Bloomington, Indiana. Indiana University. 